\title{
IMPACT OF DESTINATION IMAGE ON TOURIST SATISFACTION: THE MODERATING EFFECT OF INFORMATION TECHNOLOGY (IT)
}

\author{
Shirley Kha-Sien CHIA \\ Universiti Malaysia Sarawak, Faculty of Economics and Business, 94300 Kota Samarahan, Sarawak, Malaysia, e-mail: shirleychia0525@gmail.com \\ May-Chiun LO* \\ Universiti Malaysia Sarawak, Faculty of Economics and Business, 94300 Kota Samarahan, Sarawak, Malaysia, e-mail: mclo@unimas.my
}

Zaidi Bin RAZAK

Sarawak Multimedia Authority (SMA), Level 5, Bangunan Yayasan Sarawak, Jalan Masjid, Kuching, Sarawak, Malaysia, e-mail: drzaidi@ sma.gov.my

Yin Chai WANG

Universiti Malaysia Sarawak, Faculty of Computer Science \& Information Technology, Kota Samarahan, Sarawak, Malaysia, e-mail: ycwang@unimas.my

Abang Azlan MOHAMAD

Universiti Malaysia Sarawak, Faculty of Economics and Business, 94300 Kota Samarahan, Sarawak, Malaysia, e-mail: maazlan@unimas.my

Citation: Chia, S.K.S., Lo, M.C., Razak, Z.B., Wang, Y.C., \& Mohamad, A.A. (2021). IMPACT OF DESTINATION IMAGE ON TOURIST SATISFACTION: THE MODERATING EFFECT OF INFORMATION TECHNOLOGY (IT). GeoJournal of Tourism and Geosites, 34(1), 88-93. https://doi.org/10.30892/gtg.34112-623

\begin{abstract}
Tourism is a multifaceted field and in order to understand its complexity, none of its components should be excluded. Based on the opinions and thoughts of tourists, this research aims to determine to what extent the destination image has an impact on the satisfaction towards that destination. Survey data was collected from tourists who visited key tourist attractions in Kuching, Sarawak. SmartPLS 3 was applied to assess the developed model based on path modeling and bootstrapping. The results revealed that political images, cultural images, and infrastructure factors on destination image are positively related to tourist satisfaction. It was found that information technology (IT) does not play any moderating role in the relationships between destination image and tourist satisfaction. Results further indicated that the tourism industry can be improved for getting satisfaction among tourists by offering a better development on significant destination image in Sarawak.
\end{abstract}

Key words: destination image, tourist satisfaction, information technology, tourism, Sarawak

$$
* \quad * \quad * \quad * \quad * \quad *
$$

\section{INTRODUCTION}

Tourism plays a main role in contributing to economic growth which is an integral part of economic, social, regional and physical development. In 2018, tourism performance of the world grew 5\% of international tourist arrivals which successfully reached to the 1.4 billion arrivals as well as generated USD 1.7 trillion of export earnings from tourism (UNWTO, 2019). Based on the fact, the tourism industry is one of the most important contributors to the growth of Malaysia (Kushwah and Chaturvedi, 2019). The tourism industry is the third-largest contributor in Malaysia which is accounting for more than $7.0 \%$ of the country economy. In 2018, the tourism industry has generated revenue with a total of RM 11.0 billion for Sarawak as well as contributed 7.5\% to Gross Domestic Product (GDP) of Sarawak (DOSM, 2018). Based on the statistics provided by the Ministry of Tourism, Arts and Culture Sarawak, the visitor arrivals into Sarawak were decreased from 4.9 million in 2017 to 4.4 million in 2018. Sarawak consists of various resources, indigenous long-house cultures and famous with its colonial White Rajahs which could be the base for a formidable extraordinary interest tourism industry (Douglas and Douglas, 1999).

Moreover, countries that experience low levels of tourist satisfaction witness significant reductions in tourism businesses. Tourists will not revisit the same destination if they feel dissatisfied, which may cause a significant decline in the tourism economy (Khoshne vis Yazdi et al., 2017). The global competitiveness of the tourism industry has underlined the importance of destination image as one of the best ways to strengthen the competitive advantages of a destination as well as increasing the quality of tourism destination. Park et al. (2019) demonstrated that tourists reported lower satisfaction level with destination quality as well as its image after they have revisited the destination. This underlines the need for a better understanding of the factors that influence tourist satisfaction and revisit intention which are needed for developing a desirable destination in a region (Zainuddin et al., 2016). In this regard, the power of destination image is acknowledged universally due to its effect on perception, consequent behavior, and destination choice of tourists (Zhang et al., 2018). This connotation has accelerated tourism authorities and tourism destinations to constantly develop sustainable destination image among the tourists (Bornhorst et al., 2010; Buhalis, 2000; Pike and Page, 2014). Various ways could enhance tourists' visitation and one of them is through information technology.

The use of information technology may influence the stereotypical images of people to a certain destination and hence, information system (IT) is used as a moderator in this research to identify whether it has an impact on destination image delivery on tourist satisfaction. In short, this research examines the direct impact of destination image (political, economic, environmental, cultural and infrastructure) towards the tourists' satisfaction. The present study investigates tourists who visited Kuching Waterfront, Damai Beach, and Sarawak Cultural Village in the city of Kuching, Sarawak. By understanding the potential strengths and vitality of Sarawak tourism destination through destination images among tourist, this enables researchers to identify the main thrust in developing a tourism destination competitiveness for Sarawak.

\section{LITERATURE REVIEW AND DEVELOPMENT OF HYPOTHESES}

Social Exchange Theory and Tourist Satisfaction

Social exchange theory explains a framework which indicates how individuals are contingent on rewarding actions from others

\footnotetext{
* Corresponding author
} 
(Emerson, 1976). Subsequently, this theory has been commonly implemented to consider the perceptions, attitudes and satisfaction level of tourist towards tourism (Coulson et al., 2014). According to Casaló and Romero (2019), social exchange theory has been employed in their research to examine the influence of social media promotions on the perception of tourist that generates value for tourists, simultaneously, encourages tourists to create value as a reward that benefits firms as well. In short, this study constructs destination image as materials and resources in tourism that involved in an exchange process with tourist satisfaction by using information technology to accelerate the benefit and rewards among both parties. Hence, travelers are likely to choose a destination for traveling when benefits, security accrued, feelings and gifts from such a destination are better than something they preferred. In deciding tourism destinations, revisit intention and tourism products, tourists will consider their satisfaction as the paramount importance and therefore, tourists satisfaction is considered as a major concept in tourism (Chen and Tsai, 2007; Prayag, 2009; Upadhya and Vij, 2020). As such, most of the studies indicated that tourist satisfaction is an important factor in choosing a destination (Castro et al., 2007; Roy et al., 2016; San Martín et al., 2019; Song and Cheung, 2010; $\mathrm{Wu}$ et al., 2018). Since satisfaction is generally regarded as a crucial factor among tourists and every tourist have their personal preferences and opinions, it is vital to place tourist's satisfaction as principal importance in tourism research.

\section{Destination Image}

Destination image is defined as the impressions towards a place (Hunt, 1975) and was first considered as an important factor in the destination selection process in 1970 (Mayo, 1975). Most researchers qualified that a place with the positive and unique image possess a high possibility to be chosen as a vacation destination by tourists (Baloglu and Love, 2005; Toral et al., 2018; Um and Crompton, 1990). The importance of destination image has been summarized as understanding the impact of destination on tourist satisfaction for building favorable brand image to improve destination's attractiveness and thereby enhance economic development in that destination (Hankinson, 2004; Hwang and Lee, 2019). Hence, destination image has been considered as the fundamental of tourism development for promoting a tourism place by accessing the destination image to potential tourists strategically. However, attaining tourist's satisfaction is challenging as destination image varies with different experiences in terms of educational, emotional and social (Prayag et al., 2017). Furthermore, political condition, destination environments, pricing, travel costs, festivals, history, accessibility and hospitality are attributes employed to measure a destination image (Chi et al., 2008; Echtner and Ritchie, 1991; Girma and Singh, 2019; Zhou, 2014). The power of destination image has been acknowledged universally because of the extreme effect on subjective perception, consequent behavior and destination choice of tourists (Zhang et al., 2018). Therefore, this research employs political image, economics image, environmental image, cultural image, and infrastructure factor as the sub-components of destination image, in investigating their relationships with tourist satisfaction.

\section{Political Image}

Rosenberg et al. (1991) discovered that the favorable political image has been always used in a country as an effective component for shaping the appearance and in manipulating the vote. Public image is defined as a political image which is commonly introduce d to the native population (Fatehi-Sedeh and Safizadeh, 1989; Pan, 2019). Abdou (2017) concluded that tourists tend to consider personal safety and security issues, trust and confidence level towards travel destination. While Oosthuizen and Ferreira (2019) recommended that tourism industries are encouraged to highlight the political condition of the destination for potential tourists as a marketing tool that provides a safe environment within destinations. Additionally, the political image that portrays the negative political environment of destination will have a negative image that may impact the sustainability of tourism development (Akbar et al., 2020). Therefore, this research aims to confirm the formulated hypothesis:

H1: There is a positive relationship between political image and tourist satisfaction.

\section{Economic Image}

Economic image is explained as individuals' impression and perception on the cost, the value of products or services and in term of money (Zeithaml, 1988). On the other hand, Ghose and Johann (2018) concluded that the reasonable price of a destination is not significant enough to influence tourist satisfaction. Moreover, Setiawan et al. (2020) elucidate that price fairness is regarded as an economics image for tourists and played an important role to build trust between both travelers and destination. Simultaneously, technological and market innovations which work together with a purpose of shared economy has been widely explored, and these show a strong impact on distribution, consumption, and production of tourism goods and services, as well as, significantly impinging on the supposed beneficial strategy of tourism's development and tourism destination governance ( $\mathrm{Yu}$ and Duverger, 2019). A positive tourism experience is linked with a higher recommendation by tourists, and hence, it helps to result in a higher possibility of revisit intention (Hashemi et al., 2019). Therefore, this research formulates the following hypothesis:

$\mathrm{H} 2$ : There is a positive relationship between economics image and tourist satisfaction.

\section{Environmental Image}

Jin et al. (2015) highlighted that environmental image refers to the individual's impression and perception towards a place when tourists travel to a certain tourism destination. The quality of a destination environment effectively attributes an image within the travelers which are also developing tourist's loyalty and a better satisfaction level to such destination (Lai, 2018). The contribution of a superior tourist environmental experience is to strengthen tourist's future revisit intention as well as to associate with tourist's willingness for giving recommendations to others about the destination that they are satisfied with (Meng and Cui, 2020). However, due to the different interests of tourists, the different result of environmental images among tourists results in an inconsistent tourist satisfaction towards the same destination (Martin et al., 2019). For instance, an urban environment setting of a destination results in a high satisfaction level of tourists who prefer urban setting, while tourists who prefer rural tourism significantly shows a low level of satisfaction (Lam-González et al., 2019; López-Guzmán et al., 2017). With that, this study aims to confirm the formulated hypothesis:

H3: There is a positive relationship between environmental image and tourist satisfaction.

\section{Cultural Image}

Cultural image refers to the impression and experiences in the mind of an individual to interpret characteristics of a destination's literature, ethics, clothing, language, architecture, cuisine, arts and music (Chieng, 2019; Wells and McFadden, 2006). Ling et al. (2010) found that food contributes towards an image that strengthens the desire of tourist's repeat visitation to experience the unique food culture within destinations. Hashemi et al. (2019) stated that the destination image of heritage which works as a tourist's perception positively affects satisfaction level and revisit intentions among tourists. Additionally, Hidayat et al. (2020) confirmed that festivals celebrated at destinations influence tourist satisfaction. Therefore, the following hypothesis is formulated:

$\mathrm{H} 4$ : There is a positive relationship between cultural image and tourist satisfaction. 


\section{Infrastructure Factor}

Tourism infrastructure works as an innovation tool for a destination to enhance better goods and services for tourist as well as increase the destination quality (Liu et al., 2017). Past studies (Chi and Qu, 2008; Isa et al., 2018) concluded that unique and excellent infrastructure images such as accommodation facilities, accompanying facilities, communication facilities, and accessibility significantly accelerates a good image contribution among tourists towards a destination. Moreover, the infrastructure of destination image has been verified as the most significant element that influences tourist satisfaction to ease various tourism activities which can be accessed within destinations and tourists (Khuong et al., 2020). Therefore, the following hypothesis is developed:

H5: There is a positive relationship between infrastructure factor and tourist satisfaction.

\section{Information Technology}

IT is the storing, processing, and dissemination of pictorial, graphic, vocal and any information by using a microelectronics-based association of telecommunications and computing (Longley and Shain, 1985). The most significant benefit associated with the steps into the technologies is the enhancement in the relevant information supply as well as the reduction of production costs in innovation fields or sectors (Sher and Lee, 2004; Wu et al., 2006; Von Hippel, 1994). Moreover, IT provides the impulse in the formation of interest and motivation as well as to satisfy tourists based on visual cues and to visit the destination physically (Marasco et al., 2018). By utilizing IT, this simplifies and increases the utilization of technology for tourists as well as other innovations within tourism industries (Kim et al., 2020). Indeed, IT provides access to both the demand and supply of tourism industries by enhancing the competitive advantages. This underlines that IT possesses a strong relationship between tourism destinations and tourist satisfaction (Okumus et al., 2019). Therefore, this research aims to confirm the formulated hypothesis as follows:

H6: Information Technology (IT) moderates the relationship between the destination images and tourist satisfaction.

\section{MATERIALS AND METHODS}

This research aims to assess tourist's satisfaction who are traveling in Kuching, Sarawak which depends on the tourist's destination image. The setting of this study was at Damai Beach, Sarawak Cultural Village and Kuching Waterfront. This research employs purposive sampling technique for choosing non-Sarawak resident visitors at the age of 18 and above years old to participate. G*Power (version 3.1.9.7) software has been used to calculate the minimum sample size (Faul et al., 2009). Based on the calculations, a minimum sample size of 92 was needed for this research. In total, 223 sets of questionnaires were distributed to the targeted tourist s in the selected sites, in which 196 sets were returned, which indicated an $88 \%$ response rate. The questionnaires of this study were modified from past researches in adapting the Sarawak tourism context. The present survey questionnaires consist of Section A (Demographic Information) with 6 statements, and Section B which included Part I (Destination Images) and (Imagine the following situation) with a total of 25 statements, Part II (Destination Loyalty) with 8 statements, and Part III (Revisit Intention) with 6 statements. Additionally, the 5-points Likert scale has been used in Part I and Part III, while, Part II conducts 7-points Likert scale for assessing its statements. SmartPLS 3 has been used for data analysis in path modeling and followed by bootstrapping model (Wetzels et al., 2009).

Table 1. Respondents Demographic Profile

\begin{tabular}{|c|c|c|c|}
\hline $\begin{array}{c}\text { Demographic } \\
\text { Variable }\end{array}$ & Category & $\begin{array}{c}\text { Respondents } \\
(N=196) \text { Frequency }\end{array}$ & Percentage \\
\hline \multirow[t]{4}{*}{ Age } & $18-24$ years old & 17 & 8.7 \\
\hline & $25-44$ years old & 88 & 44.9 \\
\hline & 45-64 years old & 73 & 37.2 \\
\hline & 65 years old and above & 18 & 9.2 \\
\hline \multirow[t]{2}{*}{ Gender } & Male & 88 & 44.9 \\
\hline & Female & 108 & 55.1 \\
\hline \multirow{3}{*}{ Marital Status } & Single & 105 & 53.6 \\
\hline & Married & 86 & 43.9 \\
\hline & $\begin{array}{c}\text { Divorced/Separated/ } \\
\text { Widowed }\end{array}$ & 5 & 2.6 \\
\hline \multirow[t]{3}{*}{ Educational } & High school or less & 47 & 24.0 \\
\hline & University Degree & 118 & 60.2 \\
\hline & Master/PhD & 31 & 15.8 \\
\hline The country of & Europe & 51 & 26.0 \\
\hline \multirow[t]{5}{*}{ residence } & Asia & 64 & 32.7 \\
\hline & North America & 31 & 15.8 \\
\hline & Australia & 19 & 9.7 \\
\hline & Latin America & 18 & 9.2 \\
\hline & Africa & 13 & 6.6 \\
\hline Average & Less than $\$ 29,999$ & 19 & 9.7 \\
\hline household & $\$ 30,000$ - \$59,999 & 61 & 31.1 \\
\hline income & $\$ 60,000-\$ 89,999$ & 59 & 30.1 \\
\hline \multirow[t]{2}{*}{ (per year) } & $\$ 90,000$ - \$119,999 & 36 & 18.4 \\
\hline & $\$ 120,000$ or more & 21 & 10.7 \\
\hline
\end{tabular}

Table 2. Result of Measurement Model

\begin{tabular}{|c|c|c|c|c|c|}
\hline Construct & Items & Loadings & CR & AVE & $\begin{array}{c}\text { Cronbach's } \\
\text { alpha }\end{array}$ \\
\hline Political Image & B1_Q2_IV_P & 0.956 & 0.953 & 0.870 & 0.925 \\
\hline & B1_Q3_IV_P & 0.943 & & & \\
\hline & B1_Q4_IV_P & 0.898 & & & \\
\hline Economic Image & B1_Q5_IV_Ec & 0.832 & 0.902 & 0.698 & 0.861 \\
\hline & B1_Q6_IV_Ec & 0.707 & & & \\
\hline & B1_Q7_IV_Ec & 0.923 & & & \\
\hline & B1_Q8_IV_Ec & 0.864 & & & \\
\hline Environmental Image & B1_Q9_IV_En & 0.921 & 0.905 & 0.761 & 0.874 \\
\hline & B1_Q10_IV_En & 0.881 & & & \\
\hline & B1_Q11_IV_En & 0.811 & & & \\
\hline Cultural Image & B1_Q13_IV_C & 0.786 & 0.922 & 0.799 & 0.899 \\
\hline & B1_Q14_IV_C & 0.960 & & & \\
\hline & B1_Q15_IV_C & 0.926 & & & \\
\hline Infrastructure Factor & B1_Q18_IV_In & 0.732 & 0.829 & 0.618 & 0.701 \\
\hline & B1_Q19_IV_In & 0.858 & & & \\
\hline & B1_Q20_IV_In & 0.763 & & & \\
\hline Tourist Satisfaction & Mean_Lo & 0.967 & 0.961 & 0.925 & 0.920 \\
\hline & Mean_Re & 0.957 & & & \\
\hline Information Technology & B1_IT_Q1 & 0.821 & 0.866 & 0.765 & 0.703 \\
\hline & B1_IT_Q2 & 0.925 & & & \\
\hline & & & & & \\
\hline & & & & & \\
\hline & & & & & \\
\hline & & & & & \\
\hline & & & & & \\
\hline & &
\end{tabular}

\section{FINDINGS}

\section{Assessment of the Measurement Model}

Confirmatory factor analysis was conducted to examine the reliability, discriminant validity and convergent validity that assessed the measurement model for this study. As revealed in Table 2, items' factor loadings are greater than 0.7, as suggested by Hair et al. (2013). Moreover, the entire composite reliability (CR) shows above the minimum point of 0.7 (Chin, 1998), while the average variance extracted (AVE) demonstrated the figure at least 0.6 which is greater than the suggested minimum point of 0.5 (Bagozzi and Yi, 1988; Fornell and Larcker, 1981). These figures inferred that the result of the measurement model has complied. As depicted in Table 3, the bolded square root of all AVEs is higher than the other entries (correlations). Therefore, this discriminant validity of the constructs is fulfilled.

\section{Assessment of the Structural Model}

Table 4 and Figure 1 show the results of hypotheses testing. The path coefficients are vital to be significant in research, whereas the value of $\mathrm{R}^{2}$ can change irregularly. Depends on the study area, as the suggested value of $0.19,0.33$, and 0.67 are deemed as weak, moderate, and substantial (Chin, 1998). As described in Table 4, there are three hypotheses out of six were supported, that is, H1, H4 and H5. The 
results revealed that political image $(\beta=0.500$, t-statistics $=7.293)$, cultural image $(\beta=0.259$, t-statistics $=3.900)$, and infrastructure factor $(\beta=0.314,7.116)$ are positively significant and related to tourist satisfaction. Other than that, the finding of H2, H3, H6 do not resonate well with the results of the past researches. As shown in Figure 1, the $\mathrm{R}^{2}$ value of this research is 0.701 that deemed as substantial.

Table 3. Discriminant Validity of Constructs

\begin{tabular}{|l|c|c|c|c|c|c|c|}
\hline Construct & 1 & 2 & 3 & 4 & 5 & 6 & 7 \\
\hline 1. Cultural Image & $\mathbf{0 . 8 9 4}$ & & & & & & \\
\hline 2. Economic Image & 0.382 & $\mathbf{0 . 8 3 5}$ & & & & & \\
\hline 3. Environmental Image & 0.499 & 0.701 & $\mathbf{0 . 8 7 2}$ & & & & \\
\hline 4. Information Technology & 0.010 & 0.050 & 0.047 & $\mathbf{0 . 8 7 4}$ & & & \\
\hline 5. Infrastructure Factor & 0.265 & 0.352 & 0.252 & -0.035 & $\mathbf{0 . 7 8 6}$ & & \\
\hline 6. Political Image & 0.502 & 0.488 & 0.388 & -0.04 & 0.510 & $\mathbf{0 . 9 3 3}$ & \\
\hline 7. Tourist Satisfaction & 0.493 & 0.296 & 0.187 & -0.171 & 0.596 & 0.713 & $\mathbf{0 . 9 6 2}$ \\
\hline
\end{tabular}

Table 4. Path Coefficient and Hypothesis Testing

\begin{tabular}{|c|l|c|c|c|c|}
\hline Hypotheses & Relationship & $\boldsymbol{\beta}$ & t-values & p-values & Decision \\
\hline H1 & Political Image $\rightarrow$ Tourist Satisfaction & 0.500 & 7.293 & $<0.001^{* *}$ & Supported \\
\hline H2 & Economics Image $\rightarrow$ Tourist Satisfaction & -0.058 & 0.874 & 0.191 & Not Supported \\
\hline H3 & Environmental Image $\rightarrow$ Tourist Satisfaction & -0.187 & 2.382 & 0.009 & Not Supported \\
\hline H4 & Cultural Image $\rightarrow$ Tourist Satisfaction & 0.259 & 3.900 & $<0.001^{* *}$ & Supported \\
\hline H5 & Infrastructure Factor $\rightarrow$ Tourist Satisfaction & 0.314 & 7.116 & $<0.001^{* *}$ & Supported \\
\hline H6 Note: $* p<.05$, & -0.131 & 2.578 & 0.005 & Not Supported \\
$*$ & Information Technology $\rightarrow$ Tourist Satisfaction & -0.01 &
\end{tabular}

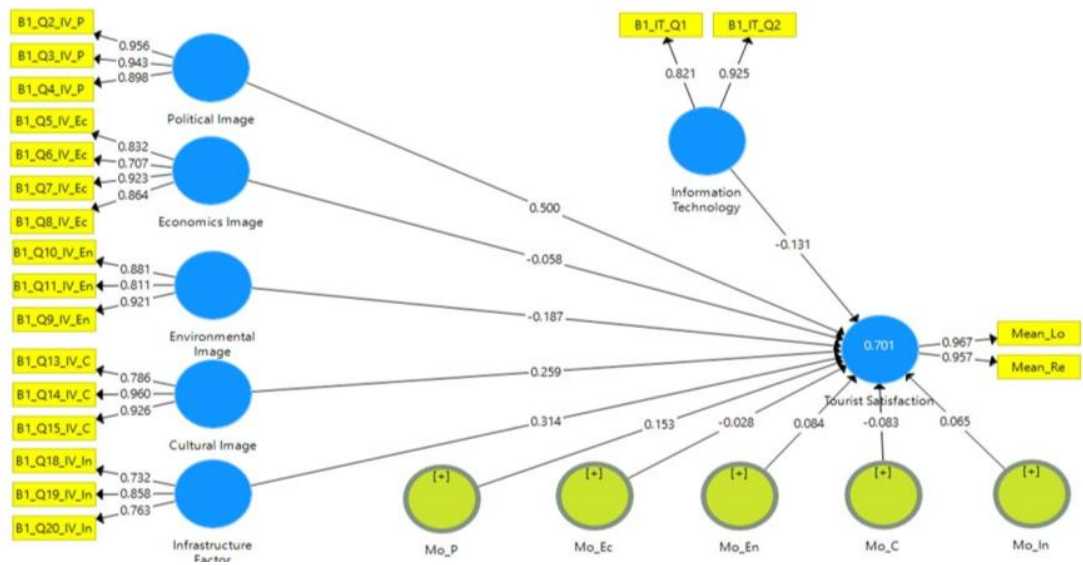

Figure 1. Research model with path coefficient and p-values

\section{RESULTS AND DISCUSSION}

The main objective of this research is to determine the relationship between destination image on tourist satisfaction and in formation technology (IT) as the moderator. As there are no known studies on how information technology moderates the relationship between destination image and tourist satisfaction. The findings have added information in this research that generated insight into potential strategies and future opportunities in tourism development of Sarawak. In analyzing H1, the result of this study supported past findings studies which stated that political image of tourist impacts in tourist destination selection process for vacation (Hankinson, 2005; Jalilvand et al., 2012; Seddighi and Theocharous, 2002; Sönmez and Sirakaya, 2002). King (2009) also confirmed that the political image consists of a positive relationship towards tourist revisit intention and destination loyalty which indicates tourist satisfaction. Moreover, it was believed that destination image plays a major role in tourists' satisfaction which is associated with tourists' loyalty towards a destination (Bhat and Darzi, 2018). Therefore, the political image on the destination image significantly showed a positive relationship with tourist satisfaction in this study. The analysis of $\mathrm{H} 4$ in this research showed that cultural image of destination image displays a positive relationship towards tourist satisfaction. As such, H4 aligns with the previous study by Coban (2012) and thereby validates that cultural image among tourist significantly impacts tourist satisfaction. Besides, the past study verified that festivities of a destination influence tourist satisfaction, while the event quality of the festivals does not significantly impact the level of tourist satisfaction (Hidayat et al., 2020).

As a result, cultural image is significant in enhancing destination image among tourist, which in turn, improves the attractiveness of tourism destination by presenting cultural aspects of destination effectively. Past studies (Chi and Qu, 2008; Isa et al., 2018) concluded that unique and excellent infrastructure factors such as accommodation facilities, accompanying facilities, communication facilities, and accessibility significantly accelerates a good image contribution among tourists towards a destination. Moreover, the infrastructure of destination image has been verified as the most significant element that influences tourist satisfaction that would ease various tourism activities to be accessed within destinations and tourists (Khuong et al., 2020). Therefore, H5 is supported. The present study has extended the research in destination image towards tourist satisfaction in Sarawak with information technology as the moderating variable. Through the findings of this research, it was also revealed that information technology does not influence the relationship between destination image and tourist satisfaction. Therefore, the findings of this study have added to the body of knowledge for managing tourism industries in Sarawak.

\section{CONCLUSION}

In summary, the political image, cultural image, and infrastructure factors significantly showed a positive relationship with tourist satisfaction in this study. This study has provided us with additional comprehension on destination image and how each dimension (i.e. political image, economic image, environmental image, cultural image, and infrastructure factors) impacts the satisfaction of tourists.

The findings of this research underlined social exchange theory as a relevant theory to govern the outcome of destination image towards tourist satisfaction based on the fundamental rule of "costs vs benefits". The results accentuate that the political image, cultural image, and infrastructure factors on destination image are significant in ensuring tourist satisfaction. Moreover, from this study, the results contributed to 
the literature on destination image from the Sarawak tourism context. From the practitioner's perspective, the findings provided a better understanding of the tourism industry to verify and comprehend the effectiveness of tourism development to positively conduct a favorable destination image that would enhance tourists' satisfaction. The data from this study is gathered from the non-residence of Sarawak based on their travel experiences. Hence, the findings are useful to recognize the current destination image perceptions among tourists towards Sarawak tourism, that would enable local authorities to conduct strategic planning in Sarawak tourism development. There are several limitations highlighted in this research. Firstly, the sample size with a total of 198 tourists in this research does not reflect the results of several tourists who are travelling in Sarawak. Secondly, this research is designed to investigate tourist satisfaction without any specific set of pre-experiences or after-experiences of visitors. Hence, the results of this study do not represent consistency in terms of experiences among tourists. Future studies may carry out a specific setting on targeted respondents either pre-experiences or after-experiences visitors to participate in research with a similar topic. To conclude, future studies may expand the scope of the study to increase the numbers of respondents and subsequently generate better findings for representing tourist satisfaction towards destination images of Sarawak.

\section{Acknowledgement}

The funding for this project was made possible through the research grant obtained from Sarawak Multimedia Authority and Universiti Malaysia Sarawak.

\section{REFERENCES}

Abdou, P. (2017). Winners and Losers in the Tourism and Hospitality Industry along the Transition Process: Evidence from South and North MED Countries. FEMISE Research Paper No. FEM41-04. http://dx.doi.org/10.2139/ssrn.2918446

Akbar, I., Yang, Z., Han, F., \& Kanat, G. (2020). The influence of negative political environment on sustainable tourism: A study of Aksu-Jabagly World Heritage Site, Kazakhstan. Sustainability, 12(1), 1-18. http://dx.doi.org/10.3390/su12010143

Bagozzi, R.P., \& Yi, Y. (1988). On the evaluation of structural equation models. Journal of The Academy of Marketing Science, 16(1), 74-94. https://doi.org/10.1007/BF02723327

Baloglu, S., \& Love, C. (2005). Association meeting planners' perceptions and intentions for five major US convention cities: the structured and unstructured images. Tourism Management, 26(5), 743-752. https://doi.org/10.1016/j.tourman.2004.04.001

Bhat, S.A., Darzi, M.A., \& Parrey, S.H. (2018). Antecedents of customer loyalty in banking sector: A mediational study. Vikalpa, 43(2), 92-105. https://doi.org/10.1177/0256090918774697

Bornhorst, T., Ritchie, J.B., \& Sheehan, L. (2010). Determinants of tourism success for DMOs \& destinations: An empirical examination of stakeholders perspectives. Tourism Management, 31(5), 572-589. https://doi.org/10.1016/j.tourman.2009.06.008

Buhalis, D. (2000). Marketing the competitive destination of the future. Tourism Management, 21(1), 97-116. https://doi.org/10.1016/S0261-5177(99)00095-3

Casaló, L.V., \& Romero, J. (2019). Social media promotions and travelers' value-creating behaviors: The role of perceived support. International Journal of Contemporary Hospitality Management, 31(2), 633-650. https://doi.org/10.1108/IJCHM-09-2017-0555

Castro, C.B., Armario, E.M., \& Ruiz, D.M. (2007). The influence of market heterogeneity on the relationship between a destination's image and tourists future behaviour. Tourism Management, 28(1), 175-187. https://doi.org/10.1016/j.tourman.2005.11.013

Chen, C.F., \& Tsai, D. (2007). How destination image and evaluative factors affect behavioral intentions? Tourism Management, 28(4), 1115-1122. https://doi.org/10.1016/j.tourman.2006.07.007

Chi, C.G., \& Qu, H. (2008). Examining the structural relationships of destination image, tourist satisfaction and destination loyalty: An integrated approach Tourism Management, 29(4), 624-636. https://doi.org/10.1016/j.tourman.2007.06.007

Chieng, J. (2019). Sound properties, festival experience and soundscape perception of the Rainforest World Music Festival in Sarawak Cultural Village, Malaysia. (Doctoral thesis, University of Sheffield)

Chin, W.W. (1998). The partial least squares approach to structural equation modelling. In G. A. Marcoulides. Modern methods for business research, 295336, Mahwah, New Jersey: Lawrence Erlbaum Associates.

Coban, S. (2012). The effects of the image of destination on tourist satisfaction and loyalty: The case of Cappadocia. European Journal of Social Sciences, 29(2), 222-232.

Coulson, A.B., MacLaren, A.C., McKenzie, S., \& O'Gorman, K.D. (2014). Hospitality codes and social exchange theory: The Pashtunwali and tourism in Afghanistan. Tourism Management, 45, 14-141. https://doi.org/10.1016/j.tourman.2014.03.019

Douglas, N., \& Douglas, N. (1999). Towards a history of tourism in Sarawak. Asia Pacific Journal of Tourism Research, 4(1), 77-86. https://doi.org/10. 1080/10941669908722015

Echtner, C.M., \& Ritchie, J.B. (1991). The meaning and measurement of destination image. Journal of Tourism Studies, 2(2), 2-12

Emerson, R.M. (1976). Social exchange theory. Annual Review of Sociology, 2(1), 335-362. https://doi.org/10.1146/annurev.so.02.080176.002003

Fatehi-Sedeh, K., \& Safizadeh, M.H. (1989). The association between political instability and flow of foreign direct investment. Management International Review, 4-13. https://www.jstor.org/stable/40227943

Faul, F., Erdfelder, E., Buchner, A., \& Lang, A.G. (2009). Statistical power analyses using G*Power 3.1: Tests for correlation and regression analyses. Behavior Research Methods, 41, 1149-1160. https://doi.org/10.3758/BRM.41.4.1149

Fornell, C., \& Larcker, D.F. (1981). Evaluating structural equation models with unobservable variables and measurement error. Journal of Marketing Research, 18(1), 39-50. https://doi.org/10.2307/3151312

Ghose, S., \& Johann, M. (2018). Measuring tourist satisfaction with destination attributes. Journal of Management and Financial Sciences, 34, 9-22.

Girma, M., \& Singh, M. (2019). Factor affecting intention to visit destination ethiopia; Branding perspectives. International Journal of Management Science, 6(1), 1-8.

Hair, J.F., Ringle, C.M., \& Sarstedt, M. (2013). Partial least squares structural equation modeling: Rigorous applications, better results and higher a cceptance. Long Range Planning, 46(1-2), 1-12. http://dx.doi.org/10.1016/j.lrp.2013.01.001

Hankinson, G. (2004). The brand images of tourism destinations: A study of the saliency of organic images. Journal of Product \& Brand Management, 13(1), 6-14. https://doi.org/10.1108/10610420410523803

Hankinson, G. (2005). Destination brand images: A business tourism perspective. Journal of Services Marketing, 19(1), 24-32. https://doi.org/10.1108/08876040510579361

Hidayat, T., Hu, C.P., Chang, Y.Y., \& Tsai, Y.H. (2020). Tourist satisfaction on culture event: the case of Pacu Jawi (cow racing) in West Sumatra, Indonesia. International Journal of Organizational Innovation, 12(4), 150.

Hunt, D.E. (1975). Person-environment interaction: A challenge found wanting before it was tried. Review of Educational Research, 45(2), 209-230. https://doi.org/10.2307/1170054

Hwang, J., \& Lee, J. (2019). A strategy for enhancing senior tourists' well-being perception: Focusing on the experience economy. Journal of Travel \& Tourism Marketing, 36(3), 314-329. https://doi.org/10.1080/10548408.2018.1541776

Isa, S.M., Chin, P.N., \& Mohammad, N.U. (2018). Muslim tourist perceived value: A study on Malaysia Halal tourism. Journal of Islamic Marketing, 9(2), 402-420. https://doi.org/10.1108/JIMA-11-2016-0083

Jalilvand, M.R., Samiei, N., Dini, B., \& Manzari, P.Y. (2012). Examining the structural relationships of electronic word of mouth, destination image, tourist attitude toward destination and travel intention: An integrated approach. Journal of Destination Marketing \& Management, 1(1-2), 134-143. https://doi.org/10.1016/j.jdmm.2012.10.001

Jin, N., Lee, S., \& Lee, H. (2015). The effect of experience quality on perceived value, satisfaction, image and behavioral intention of water park patrons: New versus repeat visitors. International Journal of Tourism Research, 17(1), 82-95. https://doi.org/10.1002/jtr.1968

Khoshnevis Yazdi, S., Nateghian, N., \& Sheikh Rezaie, N. (2017). The causality relationships between tourism development and foreign direct investment: An empirical study in EU countries. Journal of Policy Research in Tourism, Leisure and Events, 9(3), 247-263. https://doi.org/10.1080/19407963.2017.1297310

Khuong, M., Nguyen, N., \& Nguyen, T. (2020). Elements influence international tourists' satisfaction. Management Science Letters, 10(11), 2463-2476. https://doi.org/10.5267/j.msl.2020.4.003

Kim, M.J., Lee, C.K., \& Preis, M.W. (2020). The impact of innovation and gratification on authentic experience, subjective well-being, and behavioral intention in tourism virtual reality: The moderating role of technology readiness. Telematics and Informatics, 49, 1-55. https://doi.org/10.1016/j.tele.2020.101349

King, W. R. (2009). Knowledge management and organizational learning. In W. R. King, Knowledge management and organizational learning,3-13, Boston: Springer

Kushwah, R.S., \& Chaturvedi, P. (2019). Resident's perceived economic benefits of heritage tourism and support for tourism development: A case of Khajuraho. In Proceedings of 10th International Conference on Digital Strategies for Organizational Success, 1514-1525, Gwalior: Prestige Institute of Management. http://dx.doi.org/10.2139/ssrn.3328133 
Lai, K. (2018). Influence of event image on destination image: The case of the 2008 Beijing Olympic Games. Journal of Destination Marketing \& Management, 7, 153-163. https://doi.org/10.1016/j.jdmm.2016.09.007

Lam-González, Y.E., León, C.J., \& de León Ledesma, J. (2019). Assessing the effects of the climatic satisfaction on nautical tourists' on-site activities and expenditure decisions. Journal of Destination Marketing \& Management, 14, 1-12. https://doi.org/10.1016/j.jdmm.2019.100372

Lim, C., Zhu, L., \& Koo, T.T. (2019). Urban redevelopment and tourism growth: Relationship between tourism infrastructure and international visitor flows. International Journal of Tourism Research, 21(2), 187-196. https://doi.org/10.1002/jtr.2253

Ling, L.Q., Karim, M.S.A., Othman, M., Adzahan, N.M., \& Ramachandran, S. (2010). Relationships between Malaysian food image, tourist satisfaction and behavioural intention. World Applied Sciences Journal, 10(10), 164-171. http://psasir.upm.edu.my/id/eprint/16500

Liu, X., Li, J., \& Kim, W.G. (2017). The role of travel experience in the structural relationships among tourists' perceived image, satisfaction, and beha vioral intentions. Tourism and Hospitality Research, 17(2), 135-146. https://doi.org/10.1177/1467358415610371

Longley, D., \& Shain, M. (1988). Dictionary of information technology. Boston: Springer.

López-Guzmán, T., Lotero, C.P.U., Gálvez, J.C.P., \& Rivera, I.R. (2017). Gastronomic festivals: attitude, motivation and satisfaction of the tourist. British Food Journal, 119(2), 267-283. https://doi.org/10.1108/BFJ-06-2016-0246

Marasco, A., Buonincontri, P., van Niekerk, M., Orlowski, M., \& Okumus, F. (2018). Exploring the role of next-generation virtual technologies in destination marketing. Journal of Destination Marketing \& Management, 9, 138-148. https://doi.org/10.1016/j.jdmm.2017.12.002

Martin, J.C., Saayman, M., \& du Plessis, E. (2019). Determining satisfaction of international tourist: A different approach. Journal of Hospitality and Tourism Management, 40, 1-10. https://doi.org/10.1016/j.jhtm.2019.04.005

Mayo, E. (1975). Tourism and the national parks: A psychographic and attitudinal study. Journal of Travel Research, 14(1), 14-21. https://doi.org/10. $1177 / 004728757501400103$

Meng, B., \& Cui, M. (2020). The role of co-creation experience in forming tourists' revisit intention to home-based accommodation: extending the theory of planned behavior. Tourism Management Perspectives, 33, 100581. https://doi.org/10.1016/j.tmp.2019.100581

Okumus, F., Altinay, L., Chathoth, P., \& Koseoglu, M.A. (2019). Strategic management for hospitality and tourism. UK: Routledge.

Oosthuizen, N., \& Ferreira, D. (2019). Destination enhancers influencing tourism demand. African Journal of Hospitality, Tourism and Leisure, 8(4), 1-21.

Pan, J. (2019). How Chinese officials use the Internet to construct their public image. Political Science Research and Methods, 7(2), 197-213. https://doi.org/10.1017/psrm.2017.15

Park, J.Y., Bufquin, D., \& Back, R.M. (2019). When do they become satiated? An examination of the relationships among winery tourists' satisfaction, repeat visits and revisit intentions. Journal of Destination Marketing \& Management, 11, 231-239. https://doi.org/10.1016/j.jdmm.2018.04.004

Pike, S., \& Page, S.J. (2014). Destination marketing organizations and destination marketing: A narrative analysis of the literature. Tourism Management, 41, 202-227. https://doi.org/10.1016/j.tourman.2013.09.009

Prayag, G. (2009). Tourists' evaluations of destination image, satisfaction, and future behavioral intentions - The case of Mauritius. Journal of Travel \& Tourism Marketing, 26(8), 836-853. https://doi.org/10.1080/10548400903358729

Prayag, G., Hosany, S., Muskat, B., \& Del Chiappa, G. (2017). Understanding the relationships between tourists' emotional experiences, perceived overall image, satisfaction, and intention to recommend. Journal of Travel Research, 56(1), 41-54. https://doi.org/101177/0047287515620567

Rosenberg, S.W., Kahn, S., \& Tran, T. (1991). Creating a political image: Shaping appearance and manipulating the vote. Political Behavior, 13(4), 345-367. https://www.jstor.org/stable/586121

Roy, D., Dhir, M.G.M., \& Ahsan, M.K. (2016). Factors affecting tourist satisfaction: A study in Sylhet Region. ABC Research Alert, 4(3), 9-20. https://doi.org/10.18034/abcra.v4i3.307

Ruiz, E.C., González, G.B., \& Zamora, D.T. (2018). Destination image, satisfaction and destination loyalty in cruise tourism: The case of Malaga (Spain). Tourism \& Management Studies, 14(1), 58-68. http://dx.doi.org/10.18089/tms.2018.14105

San Martín, H., Herrero, A., \& García de los Salmones, M. D. M. (2019). An integrative model of destination brand equity and tourist satisfaction. Curren Issues in Tourism, 22(16), 1992-2013. https://doi.org/10.1080/13683500.2018.1428286

Sarawak Tourism Board. (2018). Sarawak destination brief. https://sarawaktourism.com/v2/wp-content/uploads/2018/10/PressKit2018-DigitalDownload.pdf

Seddighi, H.R., \& Theocharous, A.L. (2002). A model of tourism destination choice: A theoretical and empirical analysis. Tourism Management, 23(5), 475487. https://doi.org/10.1016/S0261-5177(02)00012-2

Setiawan, E., Wati, S., Wardana, A., \& Ikhsan, R. (2020). Building trust through customer satisfaction in the airline industry in Indonesia: Service quality and price fairness contribution. Management Science Letters, 10(5), 1095-1102. https://doi.org/10.5267/j.ms1.2019.10.033

Sher, P.J., \& Lee, V.C. (2004). Information technology as a facilitator for enhancing dynamic capabilities through knowledge management. Information \& Management, 41(8), 933-945. https://doi.org/10.1016/j.im.2003.06.004

Song, H., \& Cheung, C. (2010). Factors affecting tourist satisfaction with theatrical performances: A case study of the romance of the song dynasty in Hangzhou, China. Journal of Travel \& Tourism Marketing, 27(7), 708-722. https://doi.org/10.1080/10548408.2010.519675

Sönmez, S., \& Sirakaya, E. (2002). A distorted destination image? The case of Turkey. Journal of Travel Research,41(2), 185-196. https://doi.org/10.1177/004728702237418

Toral, S.L., Martínez-Torres, M.R., \& Gonzalez-Rodriguez, M.R. (2018). Identification of the unique attributes of tourist destinations from online reviews Journal of Travel Research, 57(7), 908-919. https://doi.org/10.1177/0047287517724918

Um, S., \& Crompton, J.L. (1990). Attitude determinants in tourism destination choice. Annals of Tourism Research, 17(3), 432-448. https://doi.org/10. 1016/0160-7383(90)90008-F

Upadhya, A., \& Vij, M. (2020). Creative tourist experience: Role of destination management organizations. In Destination Management and Marketing. Breakthroughs in Research and Practice, 763-783, IGI Global.

Von Hippel, E. (1994). "Sticky information" and the locus of problem solving: Implications for innovation. Management Science, 40(4), 429-439. https://doi.org/10.1287/mnsc.40.4.429

Wells, R.H., \& McFadden, J. (2006). Human nature: act and fiction: literature, science and human nature. UK: A\&C Black.

Wetzels, M., Odekerken-Schröder, G., \& Van Oppen, C. (2009). Using PLS path modeling for assessing hierarchical construct models: guidelines and empirical illustration. MIS quarterly, 177-195. https://doi.org/10.2307/20650284

Wu, H.C., Cheng, C.C., \& Ai, C.H. (2018). A study of experiential quality, experiential value, trust, corporate reputation, experiential satisfaction and behavioral intentions for cruise tourists: The case of Hong Kong. Tourism Management, 66, 200-220. https://doi.org/10.1016/j.tourman.2017.12.011

Wu, F., Yeniyurt, S., Kim, D., \& Cavusgil, S.T. (2006). The impact of information technology on supply chain capabilities and firm performance: a resourcebased view. Industrial Marketing Management, 35(4), 493-504. https://doi.org/10.1016/j.indmarman.2005.05.003

Yu, L., \& Duverger, P. (2019). Tourism and economics: technologically enabled transactions. In E. Fayos-Solà \& C. Cooper. The Future of Tourism (pp.7191). Cham: Springer. https://doi.org/10.1007/978-3-319-89941-1 4

Zainuddin, Z., Radzi, S.M., \& Zahari, M.S.M. (2016). Perceived destination competitiveness of Langkawi Island, Malaysia. Procedia-Social and Behavioral Sciences, 222, 390-397. https://doi.org/10.1016/j.sbspro.2016.05.190

Zeithaml, V.A. (1988). Consumer perceptions of price, quality, and value: A means-end model and synthesis of evidence. Journal of Marketing, 52(3), 2-22. https://doi.org/10.2307/1251446

Zhang, J., Wu, B., Morrison, A.M., Tseng, C., \& Chen, Y.C. (2018). How country image affects tourists' destination evaluations: A moderated mediation approach. Journal of Hospitality \& Tourism Research, 42(6), 904-930. https://doi.org/10.1177/1096348016640584

Zhou, L. (2014). Online rural destination images: Tourism and rurality. Journal of Destination Marketing \& Management, 3(4), 227-240. https://doi.org/10. 1016/j.jdmm.2014.03.002

*** DOSM. (2018). Regional tourism satellite account Sarawak 2018. Retrieved from https://www.dosm.gov.my/v1/index.php?r=column/pdfPrev\&id=Qlc3c W5WRkE5cEtKYStkaUs1UzNJdz09

*** Ministry of Tourism, Arts, and Culture Sarawak. (2019). Statistic: Visitor arrivals into Sarawak. Retrieved from https://mtacys.sarawak.gov.my/page-0176-47-Statistic.html

*** UNWTO. (2019). International tourism highlights. Retrieved from https://www.e-unwto.org/doi/pdf/10.18111/9789284421152 